Byrne, C. (2018) The publications, appointments and awards (1971-2018) of James Whiston. Bulletin of Spanish Studies, 95(9-10), pp. 43-60.

(doi: $10.1080 / 14753820.2018 .1552748$ )

There may be differences between this version and the published version. You are advised to consult the publisher's version if you wish to cite from it.

http://eprints.gla.ac.uk/199130/

Deposited on: 26 November 2019

Enlighten - Research publications by members of the University of Glasgow http://eprints.gla.ac.uk 


\title{
The Publications, Appointments and Awards (1971-2017) of James Whiston
}

\author{
CERI BYRNE \\ University of Glasgow
}

\section{Thesis}

1 A Critical Study of Pérez Galdós's Fortunata y Jacinta, $\mathrm{PhD}$ thesis (Trinity College, Dublin, 1975).

\section{Books-Monographs and Editions*}

2 Juan Valera: 'Pepita Jiménez', Critical Guides to Spanish Texts 22 (London: Grant \& Cutler, 1977), 81 pp. [An examination of themes and issues arising from close study of this major nineteenth-century novel.]

3 The Early Stages of Composition of Galdós's 'Lo prohibido', Colección Támesis. Serie A-Monografías 96 (London: Tamesis, 1983), 269 pp. [The product of investigative research carried out in the Galdós Archives in Las Palmas de Gran Canaria, this book, besides offering fresh interpretations, sheds light on the novelist's narrative techniques in composing and revising Lo prohibido.]

4 Antonio Machado's Writings and the Spanish Civil War, Hispanic Studies TRAC (Textual Research and Criticism) 10 (Liverpool: Liverpool U. P., 1996), 261 pp. [An analysis of cultural and ideological issues in the Spanish Civil War, conducted in relation to the work of this leading Spanish poet and intellectual.]

5 Benito Pérez Galdós, Lo prohibido, ed., con intro., de James Whiston, Biblioteca Galdosiana (Las Palmas de Gran Canaria: Ediciones del Cabildo Insular de Gran Canaria, 1998), 482 pp. [A critical edition of the text, taking account of all its variants, together with a 50,000-word introductory study, which ranges over the author's creative process, from manuscript to the first printed edition of the novel.]

$6 \quad$ Creatividad textual e intertextual en Galdós, Ottawa Hispanic Studies 22 (Ottawa: Dovehouse Editions Canada, 1999), 230 pp. [Close textual studies of Galdós' creative processes, that also attempt to set some of the novelist's works within a wider cultural and intertextual setting.]

7 Benito Pérez Galdós, Lo prohibido, ed., con intro., de James Whiston, Letras Hispánicas 509 (Madrid: Ediciones Cátedra, 2001), 621 pp.

* The information given within square brackets about James Whiston's books and editions is largely derived from descriptions James himself included in various lists he compiled of his publications down the years. 
[Another edition of No. 5 above, published by one of Spain's largest academic publishing groups.]

Spanish Theatre: Studies in Honour of Victor F. Dixon, ed. Kenneth Adams, Ciaran Cosgrove \& James Whiston, Colección Támesis. Serie AMonografías 187 (Woodbridge: Tamesis, 2001), x + 189 pp. (Also contributor; see below, No. 59.)

9 Galdós: Our Contemporary, The Fifth Annual Pérez Galdós Lecture, 2002 [delivered in November 2002] (Sheffield: Univ. of Sheffield, 2002), 16 pp. <http://gep.group.shef.ac.uk/whiston.html> (accessed 2 November 2018). [A wide-ranging assessment of Galdós' novelistic art and preoccupations, with examples drawn from several novels, discussing his treatment of different social classes, the Church, marriage, women and family life. Particular attention is given to Fortunata y Jacinta, and to the novelist's treatment of Fortunata's death, in order to show that Galdós made significant changes to early drafts, before he finalized his handling of her death and his presentation of her character.]

10 The Practice of Realism: Change and Creativity in the Manuscript of Galdós's 'Fortunata y Jacinta' (Lewisburg: Bucknell U. P., 2004), 279 pp. [The product of researches in the Galdós Archives, Las Palmas and in the Houghton Library, Harvard University, this book provides a detailed comparison of the manuscript of the novel with its printed proofs as revised by Galdós himself, revealing the novelist's painstaking modes of narrative composition as he developed his first drafts into the masterpiece his novel became.]

11 El exilio interior: Antonio Machado, Biblioteca Crítica de las Literaturas Luso-Hispánicas 30 (Madrid: Ediciones del Orto/Minneapolis: Univ. of Minnesota, 2008), 94 pp. [An analysis of Machado's characteristically introverted yet philosophical preoccupation with the theme of exile which reveals that Machado and other writers of the Civil War generation, while still living in Spain during the conflict, suffered psychologically from the trauma of 'interior exile'; see also below, Nos 66 \& 72.]

12 Benito Pérez Galdós, Fortunata y Jacinta, ed., intro. \& notas de James Whiston, Clásicos Castalia 305-06, 2 vols (Madrid: Editorial Castalia, 2010), 1,405 pp. [A comprehensive edition of Galdós' masterpiece, the first since 1887 to rely substantially on the Harvard manuscript, complete with full commentary and detailed annotations.]

13 Spanish Prose Fiction from Cervantes to Baroja and Beyond: Essays in Honour of C. Alex Longhurst, ed., with an intro., by James Whiston \& Julia Biggane, BSS, LXXXVIII:7-8 (2011), 346 pp. (Also a contributor; see below, No. 70.)

14 'Agonia republicana': Living the Death of an Era. Essays on the Spanish Civil War, ed., with an intro,, by Susana Bayó Belenguer, Ciaran Cosgrove \& James Whiston, BSS, LXXXIX:7-8 (2012), 321 pp.; also published as a book under the title Living the Death of Democracy in Spain: The Civil War and Its Aftermath (London/New York: Routledge, 2015), xiv $+337 \mathrm{pp}$. [A volume of cultural, historical and literary essays by international specialists on this seismic era in Spain's history, offering fresh and interdisciplinary perspectives on the failure of the Second 
Republic, the Spanish Civil War, and the long Dictatorship under Franco which followed.]

15 Juan Valera, Pepita Jiménez, ed., con intro., de James Whiston (Nürnberg: Clásicos Hispánicos, EDOBNE, 2013) [ebook], 379 pp.

16 Theatre, Culture and History in Spain. Studies and Researches in Honour of Ann L. Mackenzie, ed., with preface, by James Whiston \& Ceri Byrne, with guest editor Jeremy Robbins, intro. by Don W. Cruickshank \& Victor Dixon with C. Alex Longhurst, BSS, XCII:8-10 (2015), 561 pp. (Also a contributor; see below, No. 75).

17 Benito Pérez Galdós, Tormento, ed., con intro., de James Whiston (Nürnberg: Clásicos Hispánicos, EDOBNE, 2016) [ebook], 534 pp.

\section{Edited Journal Volumes}

18 General Editor, 2002-2004, with Ann L. Mackenzie \& C. Alex Longhurst, Bulletin of Spanish Studies: LXXIX (2002), 836 pp. (includes Special Double Issue: Hispanic Modernisms, ed. Nelson R. Orringer [Issues 2-3]); LXXX (2003), 786 pp.; LXXXI (2004), 1,202 pp. (includes 3 Special Issues: Special Double Issue: Cervantes: Essays in Memory of E. C. Riley on the Quatercentenary of 'Don Quijote', ed. Jeremy Robbins \& Edwin Williamson [Issues 4-5; also published as a book (2005)]; a single Special Issue: Alternative Discourses in Early Twentieth-Century Spain: Intellectuals, Dissent and Sub-Cultures of Mind and Body, ed. Alison Sinclair \& Richard Cleminson [Issue 6]; \& Special Double Issue: The Iberian Book and Its Readers: Essays for Ian Michael, ed. Nigel Griffin, Clive Griffin \& Eric Southworth [Issues 7-8]).

19 General Editor, 2005-07, with Ann L. Mackenzie, C. Alex Longhurst \& Jeremy Robbins, Bulletin of Spanish Studies: LXXXII (2005), 875 pp. (includes Special Double Issue: Studies in Modern Hispanic Literatures in Honour of Donald L. Shaw, ed. Robin W. Fiddian \& C. Alex Longhurst [Issues 3-4] [also a contributor; see below, No. 64]; also 2 separately paginated book-length issues: Phillip B. Thomason \& Ceri Byrne, The Eighteenth-Century Theatre in Spain: A Bibliography of Criticism and Documentation, xviii + 210 pp. [Issue 7; also published as a book (2007)]; Jeremy Robbins, Arts of Perception: The Epistemological Mentality of the Spanish Baroque, 1580-1720, 289 pp. [Issue 8; also published as a book (2007)]); LXXXIII (2006), 1,175 pp. (includes Special Issue: Words in Action: Essays in Honour of John Butt, ed. Xon de Ros \& Federico Bonaddio [Issue 1]); LXXXIV (2007), 1,107 pp. (includes Special Double Issue: Latin American Studies in the UK, ed. William Rowe, Luis RebazaSoraluz \& Claudio Canaparo [Issues 4-5]).

20 General Editor, 2008-13, with Ann L. Mackenzie \& Jeremy Robbins, Bulletin of Spanish Studies: LXXXV (2008), 688 pp. (includes 2 separately paginated Special Issues: a single Special Issue: Golden-Age Essays in Commemoration of A. A. Parker, ed. Terence O'Reilly \& Jeremy Robbins, 117 pp. [Issue 6]; a Special Double Issue: 'De Moretiana Fortuna': estudios sobre el teatro de Agustín Moreto, ed. María Luisa Lobato \& Ann L. Mackenzie, 278 pp. [Issues 7-8]; also a separate Supplement: Ceri Byrne, Ann L. Mackenzie \& Graham Whitaker, Hispanic Studies Author and Subject Indexes 1923-2003. Eighty Years of the 'Bulletin of 
Spanish/Hispanic Studies', Vol. II, Author Indexes of Articles and Reviews, 683 pp.); LXXXVI (2009), 867 pp. (includes a separately paginated special Double Issue: Hesitancy and Experimentation in Enlightenment Spain and Spanish America. Studies on Culture and Theatre in Memory of I. L. McClelland, ed. Ann L. Mackenzie \& Jeremy Robbins, 269 pp. [Issues 7-8; also published as a book (2011)]; LXXXVII (2010), 1,049 pp. (includes a separately paginated single Special Issue: Madness and Melancholy in Sixteenth-and Seventeenth-Century Spain, ed. Elena Carrera, 136 pp. [Issue 8]); LXXXVIII (2011), 942 pp. (includes a separately paginated Special Double Issue: Spanish Prose Fiction from Cervantes to Baroja and Beyond. Essays in Honour of C. Alex Longhurst, ed. James Whiston \& Julia Biggane, 346 pp. [Issues 7-8] [also a contributor; see below, No. 70]; also 2 separately paginated Supplements: Ceri Byrne, Ann L. Mackenzie \& Graham Whitaker, Hispanic Studies Author and Subject Indexes 1923-2003. Eighty Years of the 'Bulletin of Spanish/Hispanic Studies', Vol. III, Subject Index of Articles, 503 pp.; Vol. IV, Subject Index of Reviews, 658 pp.; LXXXIX (2012), 986 pp. (includes 2 Special Issues: a single Special Issue: Exploring the Print World of Early Modern Iberia, ed. Alexander S. Wilkinson [Issue 4]; a separately paginated Special Double Issue: 'Agonia republicana': Living the Death of an Era: Essays on the Spanish Civil War, ed. Susana Bayó Belenguer, Ciaran Cosgrove \& James Whiston, 321 pp. [Issues 7-8; also published as a book titled Living the Death of Democracy in Spain: The Civil War and Its Aftermath (2015)]); XC (2013), 1,404 pp. (includes 2 Special Issues: a single Special Issue: Essays on Góngora's 'Polifemo' and 'Soledades', ed. Terence O'Reilly \& Jeremy Robbins [Issue 1]; a Special Double Issue: Golden-Age Essays in Honour of Don W. Cruickshank, ed. Martin Cunningham, Grace Magnier \& Aengus Ward [Issues 4-5]).

21 General Editor, 2014, with Ann L. Mackenzie, Julia Biggane \& Isabel Torres, Bulletin of Spanish Studies: XCI (2014), 1,320 pp. (includes 3 Special Issues: a Special Double Issue: Spain's 'Agonía republicana' and Its Aftermath: Memories and Studies of the History, Culture and Literature of the Spanish Civil War, ed. Susana Bayó Belenguer [Issues 12; also published as a book titled Getting It Wrong in Spain: From Civil War to Uncivil Peace (1936-1975) (2015)]; a single Special Issue: The Baroque in the Construction of a National Culture in Francoist Spain, ed. Paula Barreiro López, Carey Kasten \& Tobias Locker [Issue 5]; a separately paginated Special Double Issue: 'El dulce Moratín fue mi maestro': Eighteenth-Century Studies in Homage to Philip Deacon, ed. María Jesús García Garrosa \& Gabriel Sánchez Espinosa, 275 pp. [Issues 9-10]).

\section{Journal Articles and Contributions to Books*}

22 [with Nigel Glendinning] 'Spanish Studies, 1700-1898', in The Year's Work in Modern Language Studies, 32 (1970), ed. Ronald G. Popperwell (London: MHRA, 1971), 245-55. [The section on Galdós was contributed by J. Whiston.]

* The information given within square brackets about James Whiston's articles is largely derived from descriptions James himself included in various lists he compiled of his publications down the years. 
23 'An "lrish" Story of Jorge Luis Borges: Tema del traidor y del héroe', Hermathena. A Trinity College Dublin Review, CXIV (1972), 23-28. [On the unusual setting of a Borges story.]

24 'Language and Situation in Part I of Fortunata y Jacinta', Anales Galdosianos, VII (1972), 79-92. [An article which illustrates the importance of carrying out detailed studies of the language of Galdós and, more broadly, of the nineteenth-century Spanish novel.]

25 'The Materialism of Life: Religion in Fortunata y Jacinta', Anales Galdosianos, XIV (1979), 65-81. [Nos 25, 27 and 28 are thematic studies of the presence and function of naturalism in Galdós' greatest novel.]

26 'Las pruebas corregidas de Fortunata y Jacinta', in Actas del Segundo Congreso Internacional de Estudios Galdosianos, 2 vols (Las Palmas de Gran Canaria: Excmo. Cabildo Insular de Gran Canaria, 1979), I, 258-65 [see below, No. 32].

27 'Determinism and Freedom in Fortunata y Jacinta', BHS, LVII:2 (1980), 113-27.

28 'The Struggle for Life in Fortunata y Jacinta', Modern Language Review, 79:1 (1984), 77-87.

29 'Two Versions of Trafalgar: Galdós's Trafalgar (1873) and Manuel Marliani's Combate de Trafalgar (1850)', Forum for Modern Language Studies, 20:2 (1984), 154-64. [On Galdós' management of his source, in making the transition from history to fiction while composing his first historical novel.]

30 'Un voluntario realista: The First Part of a Reply to Azcárate's Minuta de un testamento?', Anales Galdosianos, XX:2 (1985), 129-40. [On intertextuality and intelectual life in a Galdós novel.]

31 'Leonor and the Last Three Lines of Machado's A un olmo seco', Neophilologus, 70:3 (1986), 397-405. [On the relationship between biographical documentary evidence and this lyric poem of Antonio Machado.]

32 'Las pruebas corregidas de Fortunata y Jacinta, in 'Fortunata y Jacinta' de Benito Pérez Galdós, coord. Germán Gullón, Persiles: El Escritor y la Crítica 169 (Madrid: Taurus Ediciones, 1986), 371-79. [A study of the extensive authorial corrections made to this novel; see also above, No. 26.]

33 'Una versión primitiva de Lo prohibido de Benito Pérez Galdós', Boletín de la Biblioteca de Menéndez Pelayo, LXII (1986), 255-66. [A study of the first draft of the manuscript of this Galdós novel.]

34 'The Manuscript of Galdós's Un voluntario realista', Romance Quarterly, 34:3 (1987), 351-60. [This study of the manuscript of Un voluntario realista also reproduces some of Galdós' early drafts of this historical novel.]

35 'Conciencia y sociedad en Fortunata y Jacinta', in Galdós: centenario de 'Fortunata y Jacinta' (1887-1987), coord. Julián Ávila Arellano (Madrid: Univ. Complutense de Madrid, 1989), 659-69. [A study of the way this nineteenth-century novelist portrays the relationship between human consciousness and society.] 
'The "Cubing" of Language in Antonio Machado's Juan de Mairena (1936)', in Essays on Hispanic Themes in Honour of Edward C. Riley, ed. Jennifer Lowe \& Philip Swanson (Edinburgh: Dept of Hispanic Studies, Univ. of Edinburgh, 1989), 148-69. [On the originality of Machado's prose.]

37 'Historia y proceso creativo en el Episodio nacional, Un voluntario realista, in Actas del Tercer Congreso Internacional de Estudios Galdosianos, 2 vols (Las Palmas de Gran Canaria: Excmo Cabildo Insular de Gran Canaria, 1989), II, 337-46. [On the treatment of history and fiction in a Galdós novel.]

38 'El Ideal de la humanidad para la vida de Sanz del Río y Lo prohibido de Galdós', Boletín de la Biblioteca de Menéndez Pelayo, LXVI (1990), 15565. [On intertextuality and intellectual life in this Galdós novel.]

39 'Ironía y psicología en Lo prohibido de Galdós', Romance Quarterly 2 37:2 (1990), 199-208. [On Galdós as a master of irony and characterization.]

40 'Las “misiones paradójicas" de Antonio Machado: Juan de Mairena (1936)', in Antonio Machado hoy. Actas del Congreso Internacional Conmemorativo del Cincuentenario de la Muerte de Antonio Machado, Alfar/Universidad. Investigación y Ensayo 50, 4 vols (Sevilla: Ediciones Alfar, 1990), I, 345-56. [On the originality of Machado's prose.]

41 'The Pluralism of Alarcón's El niño de la Bola', BHS, LXVII:4 (1990), 35768. [Studies on a politically conservative novelist with multicultural interests, while elucidating the 'liberal' imagination manifested more generally in the nineteenth-century Spanish novel.]

42 "Ficción verosímil" and "Realidad documentada" in the Second Series of the Episodios Nacionales', in Galdos' House of Fiction: Papers Given at the Birmingham Galdós Colloquium, ed. A. H. Clarke \& E. J. Rodgers, with the assistance of D. Mackenzie (Llangrannog: Dolphin, 1991), 1-13. [A study of the relationship between history and fiction in ten of Galdós' historical novels.]

43 'Trabajo y dinero en Lo prohibido', Crítica Hispánica, XIII:1-2 (1991), 5768. [On the importance of work and money in this Galdós novel.]

44 'La inversión de la retórica en "La vejez en los pueblos" de Miguel Hernández', in Miguel Hernández, cincuenta años después. Actas del I Congreso Internacional, coord. José Carlos Rovira, 2 vols (Alicante: Comisión del Homenaje a Miguel Hernández, 1992), II, 975-82. [A study of cultural issues in the Spanish Civil War, as comprehended through the poetry of Miguel Hernández, the soldier poet.]

45 'Heroes and Villains in Galdós: Lo prohibido and Macbeth', Anales Galdosianos, XXVII-XXVIII (1992-1993), 77-92. [On intertextuality in Galdós, making some comparisons between Lo prohibido and Shakespeare's Macbeth.]

46 'The Interplay between Author and Narrator in Lo prohibido', in $A$ Sesquicentennial Tribute to Galdós, 1843-1993, ed. Linda M. Willem, Juan de la Cuesta Hispanic Monographs. Series Homenajes 8 (Newark: Juan de la Cuesta, 1993), 41-55. [A study of first-person narration in this Galdós novel.] 
“"Más fuerte que la guerra": The Civil-War Sonnets of Antonio Machado', Modern Language Review, 88:3 (1993), 644-65. [Cultural issues in the Spanish Civil War as studied through the work of Antonio Machado.]

'La “moralidad gruesa” de Lo prohibido', Ínsula, 561 (1993), 15-16. [On irony and point of view in this Galdós novel.]

49 'Las galeradas (perdidas) de Lo prohibido', in Actas del Quinto Congreso Internacional de Estudios Galdosianos, 2 vols (Las Palmas de Gran Canaria: Excmo Cabildo Insular de Gran Canaria, 1995), I, 305-15. [A study of the extensive authorial changes made to this novel at the proof stage.]

50 “ "Obligación de opinar": The Limits of Pluralism in Manuel Azaña's $L a$ velada en Benicarló, in The Republic Besieged: Civil War in Spain 19361939, ed., with an intro., by Paul Preston \& Ann L. Mackenzie (Edinburgh: Edinburgh U. P., 1996), 241-60. [A study of cultural issues in the Spanish Civil War, as perceived through the writings of one of Spain's foremost politicians and intellectuals.]

51 'Campo, huerta, jardín, estufa: la domesticación del deseo en Pepita Jiménez', in Actas del Primer Congreso Internacional sobre Don Juan Valera, coord. Matilde Galera Sánchez (Cabra [Córdoba]: Ayuntamiento de Cabra, 1997), 265-73. [On Valera's 'managerial' approach to writing fiction.]

52 'La novela del héroe individual de Valera', in Historia de la literatura española, dir. Víctor García de la Concha, 9 vols (Madrid: Espasa-Calpe, 1995-1998), IX (II) (1998), Siglo XIX, coord. Leonardo Romero Tobar, 394-410. [A global study of Valera's novels, interpreted in light of that author's interest in the individual consciousness.]

53 ' "La virtud de la palabra": Manuel Azaña's Diaries of the Spanish Civil War', Neophilologus, 82:3 (1998), 411-24. [Cultural issues in the Spanish Civil War, explored through the writings of Manuel Azaña.]

54 'Aesthetics and the Commonplace in Galdós's Fortunata y Jacinta', Letras Peninsulares, 13:1 (2000), 297-317. [A study of Galdós' poetics of realism.]

55 'Tauromaquia galdosiana: "el verdadero sport trágico" en Fortunata y Jacinta', in Homenaje a Alfonso Armas Ayala, 2 vols (Las Palmas de Gran Canaria: Ediciones del Cabildo Insular de Gran Canaria, 2000), II, 83147. [On the oxymoron and its function in Fortunata $y$ Jacinta and in the realist novel more generally.]

56 'Tradición y modernidad en el pensamiento narrativo de Galdós: el caso de Tristana, in Actas del Sexto Congreso Internacional de Estudios Galdosianos (Las Palmas de Gran Canaria: Excmo Cabildo Insular de Gran Canaria, 2000), 685-98. [On the 'liberal' imagination in Galdós, and as illustrated in Tristana.]

57 'Jacinta y Fortunata: An Early Title for Galdós's Masterpiece', in Homenaje a John Kronik, Anales Galdosianos, XXXVI (2001), 285-98. [On the importance of Jacinta in Galdós' novel.]

58 “"República y paz": Monarchy and Militarism in Azaña's Writings on Primo de Rivera's Coup d'état of 1923', BHS, LXXVII:4 (2001), 475-91. [A 
study of dictatorship and the intellectual as experienced in early twentieth-century Spain and as presented in Azaña's writings.]

'Syntax and Semantics in the Dramatis personae of Lorca's La casa de Bernarda Alba', in Spanish Theatre: Studies in Honour of Victor F. Dixon, ed. Kenneth Adams, Ciaran Cosgrove \& James Whiston, Colección Támesis. Serie A-Monografías 187 (Woodbridge: Tamesis, 2001), 17789. [A study of the manuscript and printed version of the dramatis personae of this outstanding tragedy by Lorca.]

60 'Change and Creativity in Galdós's Writing: The First Draft of the Lo prohibido Manuscript', in New Galdós Studies: Essays in Memory of John Varey, ed. Nicholas G. Round, Colección Támesis. Serie A-Monografías 192 (Woodbridge: Tamesis, 2003), 27-41. [A reconsideration of issues discussed in No. 33, above.]

61 'The Alpha/Beta Version of the Second Half of Tristana', Anales Galdosianos, XXXVIII-XXXIX (2003-2004), 127-37. [A discussion of the differences between the earlier and later versions of this novel, showing how by making structural changes and removing the more extravagant elements of the original plot, Galdós makes the story-line and the dénouement of Tristana more in keeping with the novelist's practice of realism.]

62 'Preface' to Antonio García Gutiérrez, 'El trovador', trans., with an intro., by Robert G. Trimble, Hispanic Literature 94 (Lewiston/Queenston/Lampeter: The Edwin Mellen Press, 2004). [Explains how in this famously Romantic drama, the basic elements of war, rivalry, hatred, love, honour, shame and fear, are coherently bound together to form a dramatic plot that exploits them to the full and which is made readily intelligible to a live audience; Trimble's English translation, which gives a true account of Gutiérrez's The Troubadour, is shown to perform a valuable service to international culture.]

63 'Transformación y realismo en La razón de la sinrazón', in Actas del Séptimo Congreso Internacional de Estudios Galdosianos (Las Palmas de Gran Canaria: Excmo Cabildo Insular de Gran Canaria, 2004), 591-600. [Interprets Galdós' last novel, sometimes described as a 'fábula teatral', as a strangely incoherent mixture of the fantastic and the realistic which is best understood as a work discarded while still in draft; as a result, it failed to benefit from the great realist novelist's usual practice of meticulously revising his works before finalizing them.]

64 ' "Unas pocas palabras verdaderas": The Naming and Framing of Nature in Machado's Campos de Castilla', in Studies in Modern Hispanic Literatures in Honour of Donald L. Shaw, ed., with an intro., by Robin W. Fiddian \& C. Alex Longhurst, BSS, 82:3-4 (2005), 509-27. [An analysis of the repetitive, 'generic' language that acts as a frame within which the poet evokes and portrays the nature and landscape of Castile and/or Andalusia and imbues them with his memories, insights and emotions.]

65 'Flin-flan: la estructura de Fortunata y Jacinta', Revista de Erudición y Crítica, 1 (2006), 8-31. [Written to inaugurate the first number of this new learned journal launched through the Editorial Castalia.]

66 "Un "cursillo" machadiano de poesía en Segovia: "En tren. Flor de verbasco" de Nuevas canciones de 1924', in Hoy es siempre todavía. Curso 
Internacional sobre Antonio Machado. Córdoba, 7-11 de noviembre de 2005, coord. Jordi Doménech, Iluminaciones 20 (Sevilla: Renacimiento/Córdoba: Ayuntamiento de Córdoba, 2006), 380-401. [Discusses inter alia Machado's previously unsuspected interest in and disapproval of 'medical exile'-i.e., the early twentieth-century practice of isolating sufferers from TB in remote sanatoria, away from human society and from the many benefits (both physical and psychological) that patients could have derived from the natural and rural environment beyond the walls that enclosed them.]

67 'Committed [?] Writing in the Spanish Civil War', in Teaching Representations of the Spanish Civil War, ed. Noël Valis, Modern Language Association of America Options for Teaching (New York: Modern Language Association of America, 2007), 196-205. [This essay, contributed to a handbook compiled to assist with teaching advanced or postgraduate students about the Spanish Civil War in all its major manifestations, discusses the cultural and intellectual responses to the Civil War drawn from A. Machado and some of his contemporaries.]

68 'Antonio Machado's Manuscripts', BSS, LXXXV:4 (2008), 507-18 [reviewarticle on Colección Unicaja manuscritos de los hermanos Machado, ed. Rafael Alarcón Sierra, Pablo del Barco \& Antonio Rodríguez Almodóvar; see below, No. 126].

69 'El gallinero de Galdós y la jungla de Henry James: comparación de Tristana (1892) y Washington Square (1880)', in Actas del Noveno Congreso Internacional de Estudios Galdosianos (Las Palmas de Gran Canaria: Excmo Cabildo Insular de Gran Canaria, 2011), 93-102. [An analysis of selected aspects of two comparable or contrastable late nineteenth-century novels: Galdós' Tristana and Henry James' Washington Square.]

70 [with Julia Biggane], 'Introduction: Alex Longhurst', in Spanish Prose Fiction from Cervantes to Baroja and Beyond. Essays in Honour of C. Alex Longhurst, ed. \& intro. by James Whiston \& Julia Biggane, BSS, LXXXVIII:7-8 (2011), 1-6.

71 'Starkie, Walter Fitzwilliam (1894-1976), Hispanic Scholar and Travel Writer', in Oxford Dictionary of National Biography (Oxford: Oxford U. P., 2011), <https://doi.org/10.1093/ref:odnb/75075> (accessed 2 November 2018). [Includes comments on Starkie's travel writing and adventures in Spain and his activities while living there during World War II, acting discreetly as Churchill's man not Franco's.]

72 'Antonio Machado y el exilio de la vida', Turia, 104 (2012), 136-47. [A study of the theme and influence of exile in the life and work of Machado.]

73 'Introduction' to Juan Valera, Pepita Jiménez: A Novel, trans. Robert M. Fedorchek, Aris \& Phillips Hispanic Classics (Oxford: Oxbow Books, 2012), ix-xxviii. [Discusses inter alia Valera's 'mentalidad empresarial' ('managerial mind'), which developed from his experiences as a diplomat, typically working behind the scenes to manipulate relationships and reach agreements.]

74 'Nature and Culture in Pepita Jiménez', Anales Galdosianos, XLVII (2012), 55-69. [Discusses how Valera constructs his story of love and marriage in the agricultural and horticultural environment of provincial 
Andalusia, to illustrate how by blending a cultured urban life with a natural rural existence, a way of living and relating to others can be produced that is of benefit to body, mind and spirit.]

' "Laid in Earth": Some Physical Touches in Valera's Pepita Jiménez', in Theatre, Culture and History in Spain: Studies and Researches in Honour of Ann L. Mackenzie, ed. James Whiston \& Ceri Byrne, with guest editor Jeremy Robbins; intro. by Don W. Cruickshank \& Victor Dixon, with C. Alex Longhurst, BSS, XCII:8-10 (2015), 427-40. [The article shows how from the novel's beginning Valera prepares us for its dénouement which brings the protagonists to commit themselves to a life dependent on the daily social round and the physical and earthly environment they inhabit.]

76 'Patience and Pragmatism: Galdós's Rewriting of the Last Four Chapters of Halma', Anales Galdosianos, LII (2017), 79-89. [A comparison of the first draft of the final chapters of Halma with the significantly different and superior revised version which gave the definitive ending to Galdós' novel.]

77 'The Use and Abuse of Hospitality in Valera's Pepita Jiménez', in 'Fortiter sed Suaviter': Spanish Studies and Researches in Honour of Graeme Davies, ed., with an intro., by Ann L. Mackenzie \& Ceri Byrne, BSS, XCVI:2-3 (forthcoming 2019); available online since 2018 at <https://www.tandfonline.com/doi/full/10.1080/14753820.2017.1434334> (accessed 2 November 2018). [Discusses Valera's representation of the social practice of hospitality as engaged in and manipulated by several of the novel's main characters to bring about the positive outcome which they have desired.]

78 'The Word and the War: Soft Power and Hard Power in Three Republican Poems of the Spanish Civil War' [Invited keynote paper, on poems by Machado, Hernández and Altolaguirre, written for the conference on 'The Spanish Civil War and World Literatures', organized by the Institute of Modern Languages Research to commemorate the $80^{\text {th }}$ anniversary of the start of the Spanish Civil War (Senate House, University of London, 1112 July 2016); published for the first time in this Festschrift; see Part II.]

\section{Reviews}

79 Galdós Studies, II, ed. Robert J. Weber (London: Tamesis, 1974), x + 68 pp. (BHS, LIII:3 [1976], 252-53).

80 Juan Valera, Pepita Jiménez, ed., estudio \& notas de Luciano García Lorenzo (Madrid: Alhambra, 1977), 236 pp. (BHS, LV:4 [1978], 342).

81 Luis López Jiménez, El naturalismo y España: Valera frente a Zola (Madrid: Alhambra, 1977), vi + 385 pp. (BHS, LV:4 [1978], 342-43).

82 Geoffrey Ribbans, Pérez Galdós: 'Fortunata y Jacinta' (London: Grant \& Cutler/Tamesis, 1977), 126 pp. (BHS, LVI:3 [1979], 261-62).

83 Pedro Ortiz Armengol, Relojes y tiempo en 'Fortunata y Jacinta': cronología de una novela de Galdós (Las Palmas de Gran Canaria: Ediciones del Cabildo Insular de Gran Canaria, 1978), 87 pp. (BHS, LVII:3 [1980], 269). 
84 Peter Bly, Pérez Galdós: 'La de Bringas' (London: Grant \& Cutler/Tamesis, 1981), 100 pp. (Modern Language Review, 78:4 [1983], 947-48).

85 Stephen Gilman, Galdós and the Art of the European Novel,1867-1887 (Princeton: Princeton U. P., 1981), x + 413 pp. (BHS, LX:2 [1983], 157-58).

86 Diane F. Urey, Galdós and the Irony of Language (Cambridge: Cambridge U. P., 1982), vi + 138 pp. (Comparative Literature, 36:4 [1984], 370-73).

87 Conflicting Realities: Four Readings of a Chapter by Galdós ('Fortunata y Jacinta', Part III, Chapter IV), ed. Peter B. Goldman (London: Tamesis, 1984), 145 pp. (BHS, LXIII:1 [1986], 100-01).

88 Marie A. Wellington, 'Marianela': esencia y espejo. Cinco ensayos (New York: Senda Nueva de Ediciones, 1984), 84 pp. (BHS, LXIV:4 [1987], 37980).

89 Anthony Percival, Galdós and His Critics (Toronto/London: Univ. of Toronto Press, 1985), ix + 537 pp. (Modern Language Review, 83:1 [1988], 224-25).

90 Farris Anderson, Espacio urbano y novela: Madrid en 'Fortunata $y$ Jacinta' (Madrid: J. Porrúa Turanzas, 1985), viii + 131 pp. (BHS, LXV:2 [1988], 190).

91 Antonio Machado, Selected Poems, trans., with an intro., by Alan S. Trueblood (Cambridge, MA/London: Harvard U. P., 1982), xvi + 316 pp. (BHS, LXVII:1 [1990], 104-05).

92 Arnold M. Peñuel, Psychology, Religion and Ethics in Galdós' Novels: The Quest for Authenticity (Lanham/London: Univ. Press of America, 1987), xiii + 193 pp. (Modern Language Review, 85:2 [1990], 478-79).

93 David Henn, The Early Pardo Bazán: Theme and Narrative Technique in the Novels of 1879-89 (Liverpool: Francis Cairns, 1988), 231 pp. (Modern Language Review, 85:4 [1990], 1003-04).

94 Galdós y la historia, ed. Peter A. Bly (Ottawa: Dovehouse Editions Canada 1988), 218 pp. (Revista Canadiense de Estudios Hispánicos, 15:1 [1990], 149-51).

95 Gerard Flynn, Luis Coloma (Boston: Twayne Publishers, 1987), $\mathrm{x}+117$ pp. (Modern Language Review, 85:2 [1990], 479).

96 Juan Valera, Pepita Jiménez, con cuadros cronológicos, intro., bibliografía, notas \& llamadas de atención, documentos \& orientaciones para el estudio, a cargo de Ana Navarro \& Josefina Ribalta (Madrid: Castalia, 1988), 285 pp. (BHS, LXVII:4 [1990], 426-27).

97 The Crisis of Institutionalized Literature in Spain, ed. Wlad Godzich \& Nicholas Spadaccini (Minneapolis: Prisma Institute, 1988), 374 pp. (BHS, LXVIII:4 [1991], 545-46).

98 John Rutherford, 'La Regenta' y el lector complice (Murcia: Univ. de Murcia, 1988), 189 pp. (Modern Language Review, 86:2 [1991], 497-98).

99 Juan Ignacio Ferreras, La novela en el siglo XIX (hasta 1868) (Madrid: Taurus, 1987), 117 pp. (BHS, LXVIII:2 [1991], 338). 
100 Germán Gullón, La novela del siglo XIX: estudio sobre su evolución formal (Amsterdam: Rodopi, 1990), 135 pp. (BHS, LXIX:4 [1992], 384-85).

101 Juan Valera, Pepita Jiménez, ed. \& intro. de Enrique Rubio Cremades (Madrid: Clásicos Taurus, 1991), 308 pp. (BHS, LXX:4 [1993], 471-72).

102 Nicholas G. Round, On Reasoning and Realism: Three Easy Pieces [On (i) 'Metacriticism \& Hypercriticism'; (ii) 'Predictable Fictions: Reflections on Galdós and Some Others'; and (iii) 'Overstepping the Mark: Rayuela and Lo prohibido'] (Manchester: Dept of Spanish \& Portuguese, Univ. of Manchester, 1991), ix + 66 pp. (BHS, LXX:3 [1993], 380-81).

103 Peter Bly, Pérez Galdós: 'Nazarín' (London: Grant \& Cutler/Tamesis, 1991), 113 pp. (Modern Language Review, 88:4 [1993], 1014).

104 Akiko Tsuchiya, Images of the Sign: Semiotic Consciousness in the Novels of Benito Perez Galdós (Columbia/London: Univ. of Missouri Press, 1990), ix + 145 pp. (Romance Quarterly, 41:1 [1994], 51-52).

105 Brian J. Dendle, Galdós y la novela histórica (Ottawa: Dovehouse Editions, 1992), 106 pp. (Modern Language Review, 89:3 [1994], 785-86).

106 Galdós, ed. \& intro. by Jo Labanyi (Harlow: Longman, 1993), viii + 268 pp. (BHS, LXXI:3 [1994], 408-10).

107 Harriet S. Turner, Benito Pérez Galdós: 'Fortunata and Jacinta' (Cambridge: Cambridge U. P., 1992), xix + 122 pp. (BHS, LXXI:3 [1994], 408-10).

108 Lou Charnon-Deutsch, Gender and Representation: Women in Spanish Realist Fiction (Amsterdam/Philadelphia: John Benjamins Publishing Company, 1990), xiv + 205 pp. (Romance Quarterly, 41:1 [1994], 51-52).

109 Estudios sobre Antonio Machado, ed. Theodor Berchem \& Hugo Laitenberger (Münster: Aschendorff Verlag, 1992), 135 pp. (BHS, LXXIIL:2 [1995], 239-40).

110 María Concepción Ruiz Abellán, Cultura y ocio en una ciudad de retaguardia durante la guerra civil (Murcia, 1936-939) (Murcia: Real Academia Alfonso X el Sabio, 1993), 378 pp. (BHS [Glasgow], LXXIII:4 [1996], 473-74).

111 Roads Dreamed Clear Afternoons: An Anthology of the Poetry of Antonio Machado, trans. Carl W. Cobb (York, SC: Spanish Literature Publications, 1994), 251 pp. (BHS [Glasgow], LXXIII:1 [1996], 128-29).

112 Stephen Miller, Del realismo/naturalismo al modernismo: Galdós, Zola, Revilla y Clarín (1870-1901) (Las Palmas de Gran Canaria: Ediciones del Cabildo Insular de Gran Canaria, 1993), 214 pp. (Modern Language Review, 91:1 [1996], 244-45).

113 Benito Pérez Galdós, 'Trafalgar'; 'La corte de Carlos IV', ed., prólogo \& notas de Dolores Troncoso (Barcelona: Crítica, 1995), lxx + 561 pp. (BHS [Glasgow], LXXIV:4 [1997], 480).

114 David K. Herzberger, Narrating the Past: Fiction and Historiography in Postwar Spain (Durham, NC/London: Duke U. P., 1995), xi + 182 pp. (BHS [Glasgow], LXXIV:4 [1997], 482-83). 
115 Benito Pérez Galdós, Tristana, ed., with an intro., notes \& bibliography, by Gordon Minter (London: Bristol Classical Press, 1996), xxxix +164 pp. (BHS [Glasgow], LXXVI:2 [1999], 329-30).

116 Geoffrey Ribbans, Conflicts and Conciliations: The Evolution of Galdós's 'Fortunata y Jacinta' (West Lafayette: Purdue U. P., 1997), xv + 352 pp. (BHS [Glasgow], LXXVI:2 [1999], 328-29).

117 'Peñas arriba', cien años después. José María de Pereda: crítica e interpretación, ed. Anthony H. Clarke (Santander: Sociedad Menéndez Pelayo, 1997), 269 pp. (BHS [Glasgow], LXXVI:5 [1999], 712-13).

118 Rodolfo Cardona, Galdós ante la literatura y la historia (Las Palmas de Gran Canaria: Ediciones del Cabildo Insular de Gran Canaria, 1998), 231 pp. (BHS [Glasgow], LXXVIII:3 [2001], 390-91).

119 Antología comentada de la literatura española: siglo XIX, ed. Andrés Amorós, Manuel Camerero \& Tomás Pérez Viejo (Madrid: Editorial Castalia, 1999), 487 pp. (BSS, LXXIX:1 [2002], 116-17).

120 Andrew Ginger, Antonio Ros de Olano's Experiments in Post-Romantic Prose (1857-1884): Between Romanticism and Modernism (Lewiston/ Queenston/Lampeter: The Edwin Mellen Press, 2000), 234 pp. (Hispanic Research Journal, 4:3 [2003], 285-88).

121 Antonio Machado, Prosas dispersas (1893-1936), ed. Jordi Doménech, con intro. de Rafael Alarcón Sierra (Madrid: Páginas de Espuma, 2001), 890 pp. (BSS, LXXX:1 [2003], 130-32).

122 Philip G. Johnson, The Power of Paradox in the Work of the Spanish Poet Antonio Machado (1875-1939), preface by Geoffrey Ribbans (Lewiston/Queenston/Lampeter: The Edwin Mellen Press, 2002), xii + 243 pp. (BHS, LXXXII:1 [2005], 123-24).

123 Ramón Espejo-Saavedra, El reto de la novela histórica: narrativa y poder en Galdós, Valle-Inclán y Max Aub (Newark: Juan de la Cuesta, 2002), 172 pp. (BHS, LXXXII:1 [2005], 121-22).

124 Teresa Fuentes Peris, Visions of Filth: Deviancy and Social Control in the Novels of Galdós (Liverpool: Liverpool U. P., 2003), 216 pp. (BSS, LXXXIII:4 [2006], 573-74).

125 Benito Pérez Galdós, Episodios nacionales. Primera serie. La guerra de la Independencia, ed., intro. \& apéndices de Dolores Troncoso \& Rodrigo Varela (Barcelona: Ediciones Destino, 2005), 1,461 pp. (Anales Galdosianos, XLII-XLIII [2007-2008], 178-79).

126 Colección Unicaja manuscritos de los hermanos Machado, ed. Rafael Alarcón Sierra, Pablo del Barco \& Antonio Rodríguez Almodóvar, 9 vols (Málaga: Servicio de Publicaciones de la Fundación Unicaja, 2005). (BSS, LXXXV:4 [2008], 507-18) [review-article; see above, No. 68].

127 Noël Valis, Reading the Nineteenth-Century Novel (Newark: Juan de la Cuesta, 2005), 372 pp. (BSS, LXXXV:1 [2008], 101-03).

128 Antonio Machado's 'Cartas de amor a Pilar de Valderrama'/'Love Letters to Pilar de Valderrama'. A Facing Page Translation from Spanish into English, trans. Anna-Marie Aldaz, with a Foreword by Philip G. Johnston 
(Lewiston/Queenston/Lampeter: The Edwin Mellen Press, 2008), 265 pp. (BSS, LXXXVII:7 [2010], 1007-08).

129 Noël Valis, Sacred Realism: Religion and the Imagination in Modern Spanish Narrative (New Haven/London: Yale U. P., 2010), 356 pp. (BSS, LXXXIX:2 [2012], 312-13).

130 Studies in Honor of Vernon Chamberlain, ed. Mark A. Harpring (Newark: Juan de la Cuesta, 2011), 292 pp. (BSS, XC:6 [2013], 1055-56).

131 José María Valverde, Antonio Machado, $2^{\mathrm{a}}$ ed. (Madrid: Siglo XXI de España Editores), 223 pp. (BSS, XCIII:2 [2016], 349-51).

\section{University Appointments}

1969-1970 Awarded Research Fellowship, University of California, San Diego.

1971 Junior Lecturer, then Lecturer, Trinity College, Dublin.

1999-2009 Associate Professor, Trinity College, Dublin.

2009-2017 Associate Professor (emeritus), Trinity College, Dublin.

1991-2009 Fellow, Trinity College, Dublin.

2009-2017 Fellow Emeritus, Trinity College, Dublin.

\section{Editorships \& Memberships of Editorial Boards and Research Boards}

$1996-$

1996

$1992-2016$

2002-2005

2005-2013

$2006-$

2014

$2001 \&$

2015-2017 Member of the Editorial Advisory Committee of the Bulletin of Spanish Studies.

\section{Appointments to Learned Institutions \& Associations \& Other Honours}

1969

1999-2006

2006-2008
Awarded University Gold Medal in Modern Languages, Trinity College, Dublin.

Vice-President of the Asociación Internacional de Galdosistas.

President of the Asociación Internacional de Galdosistas. 
2000-2001 Awarded (as first recipient) the Berkeley Research Fellowship (one year's research leave) by Trinity College, Dublin.

$2001 \quad$ Awarded LittD by Trinity College, Dublin for published research'awarded only to candidates who have made an outstanding contribution to research in, and development of, their chosen subject', and 'who, in the view of the assessors, has distinguished $\mathrm{him} /$ herself by original research in letters' [quoted from TCD regulations].

2003-2004 Awarded a one-year Senior Research Fellowship from the Irish Research Council in the Humanities and Social Sciences to undertake a 'Research Edition of Galdós' Fortunata y Jacinta' [project completed and published; see above, No. 12].

2010- Member of the Royal Irish Academy.

2018- Establishment of the James Whiston Memorial Prize (funded by Taylor \& Francis, Informa) for the best article accepted annually for publication in the Bulletin of Spanish Studies.*

* Disclosure Statement: No potential conflict of interest was reported by the author. 